\title{
The Impact of Infrastructure Spending in Sub-Saharan Africa: A CGE Modeling Approach
}

\author{
Antonio Estache, ${ }^{1}$ Jean-François Perrault, ${ }^{2}$ and Luc Savard ${ }^{2}$ \\ ${ }^{1}$ ECARES, Université Libre de Bruxelles, B-1050 Brussels, Belgium \\ ${ }^{2}$ GREDI, Faculté d'Administration, Université de Sherbrooke, Sherbrooke, QC, Canada JIK 2R1
}

Correspondence should be addressed to Luc Savard, luc.savard@usherbrooke.ca

Received 26 March 2012; Revised 13 August 2012; Accepted 18 August 2012

Academic Editor: Colin C. Williams

Copyright (C) 2012 Antonio Estache et al. This is an open access article distributed under the Creative Commons Attribution License, which permits unrestricted use, distribution, and reproduction in any medium, provided the original work is properly cited.

\begin{abstract}
In this paper we construct a standard CGE model to explore the impact of scaling up infrastructure in six African countries. As the debate on the importance of scaling up infrastructure to stimulate growth and provide a push to African economies, some analysts raise concern on financing these infrastructures after construction and that external funding of these can create major distortion and have a negative impact on the trade balance of these countries. This study aims to provide insights into this debate. It draws from the infrastructure productivity literature to postulate positive productive externalities of new infrastructure and Fay and Yepes (2003) for operating cost associated with new infrastructure. We compare various infrastructure investments funded with different fiscal tools. These investments scenarios are compared to nonproductive investment that can be interpreted as a business as usual scenario. Our results show that foreign aid does produce Dutch disease effects but the negative impacts are strongly dependent on the type of investments performed. Moreover, growth effects contribute to attenuate the negative effects.
\end{abstract}

\section{Introduction}

For a number of years, economists have pointed out the existence of a positive relation between investments in public infrastructure and the productivity of the private sectors of the economy [1]. Since Aschauer [2] and Munnell [3] stressed the important role of the public sector in funding infrastructure to stimulate economic development, a vast literature has dealt with this issue. Theoretical models and empirical studies have attempted to shed some light on this relationship. Some authors believe that a decline in productivity would be induced by slow expansion of the public infrastructure investment in the past [4-6]. In policy circles, the role of infrastructure was somewhat neglected in the context of the stabilization and structural adjustment programs of the mid-eighties and nineties. For many international institutions and developing countries, the focus was directed at liberalizing trade, improving macroeconomic balances, and reacting to various external shocks. With improvements in these areas yet sluggish results in terms of poverty reduction in many countries, the end of the nineties saw major changes in development strategies by international financial institutions (IFI), development partners, and governments of developing countries.

According to Estache [7], infrastructure appears to be returning to the research agenda of development economists. This reflects a change in priorities of developing country governments, IFIs and multi- and bilateral donor agencies bringing infrastructure back to the top of the policy agenda. The Asian Development Bank [8] published a report on investing in sustainable infrastructure to improve lives. In many developing countries, growth is constrained by infrastructure bottlenecks, and this is reflected in many investment climate surveys in which infrastructure ranks as the top priority [7]. Estache [7] provides an interesting survey of the state of infrastructure for development and reviews the main issues for policy makers in developing countries and donor agencies.

In many countries, infrastructure growth has not kept up with economic and demographic growth and in some instances, infrastructure was not even maintained. This situation has led many analysts to return to the literature linking 
public expenditure to infrastructure. These stakeholders have argued that major investments to scale up infrastructure levels would transform their role from a constraint to an engine of growth that would contribute indirectly to poverty reduction in the long term. In a recent comprehensive report sponsored jointly by the African Development Bank, the World Bank, and the Agence Française pour le Développement, edited by Foster and Briceño-Garmendia [9], it was found that half of Africa's growth was generated by infrastructure. In the report, the authors argue that improved infrastructure will accelerate urbanization, which has been the engine for growth in many countries and will also improve regional integration.

At the same time, some researchers, such as Gupta et al. [10], Foster and Killick [11], and Mckinley [12], have suggested that scaling up aid could have negative macroeconomic consequences, notably through Dutch disease (i.e., in which foreign inflows contribute to a real exchange rate appreciation that adversely affects a country's international competitiveness). These conclusions have been challenged by others in empirical studies such as Berg et al. [13] for five Sub-Saharan African countries, Li and Rowe [14] for Tanzania and Mongardini, and Rayner [15] for a panel of 28 Sub-Saharan African countries. Many researchers have also investigated the impacts or challenges of scaling up aid to achieve the Millennium Development Goals (MDG), notably Bourguignon and Sundberg [16] and Hailu [17]. Although the debate has not been settled, concern for risks associated with a large scaling up of aid (for infrastructure or other expenditures) continues to prevail in many policy circles.

Another important and controversial question is whether public infrastructure spending will decrease private investment (crowding-out effect) or will have a multiplier effect (complementarity). For example, Abdullatif [18] asserts, for Japan between 1998 and 2006, that productive investments of the Japanese government financed by the issuing of bonds had a positive effect on the private sector. Based on an econometric model, Ahmed and Miller [19] suggest that expenditures in a social assistance program reduce private investment for both developed and developing countries.

The choice of funding scheme is also a key issue to scale up infrastructure. Using inefficient funding scheme could attenuate the positive returns of public infrastructure. It is therefore important to select the most appropriate mode to fund infrastructure construction. Authors such as Savard [20] and Bayoudh [21] have investigated this issue using CGE models in developing economies and Boccanfuso et al. [22] for a developed economy.

In this paper, we apply CGE static models to six African countries to perform a comparative analysis of funding mechanisms to finance infrastructure investment and associated $\mathrm{O}$ and $\mathrm{M}$ costs. We build on work by Adam and Bevan [23] and Levy [24], who explore how infrastructure investments funded through foreign aid can contribute to Dutch disease. In their 2006 paper, Adam and Bevan show that the impact of Dutch disease can be attenuated if nontradable sectors also benefit from infrastructure investment externalities. They construct an aggregate model and apply it to Uganda to verify this. A comparative analysis will allow us to determine if the case of Uganda set out in Adam and Bevan [23] is a special scenario or not. We extend this idea by dropping the dichotomous classification of sectors as tradable and nontradable since pure tradable and nontradable sectors are a rare occurrence in African economies. Moreover, we take into account differentiated externalities of infrastructure spending; a disaggregated model allows for a matrix of externalities among both the productive sectors and the type of infrastructure expenditure. For this exercise, we draw on Savard and Adjovi [25], who analyze the externalities of health and education investment in different productive sectors. We also introduce an additional element by imposing increases in public expenditure to maintain and repair the new public infrastructure as in Savard [20]. We further extend previous work by performing a cross country comparative analysis to highlight the role and contribution of the structure of the different African economies selected. We also perform a comparative analysis with nonproductive infrastructure investments. In fact this non-productive scenario can be interpreted as one that does not take into account the positive externalities of scaling up infrastructure.

The paper is structured as follows. We explain importance of using CGE models before moving to the presentation of the models. We follow by a presentation of the countries selected and the social accounting matrix. The next section is dedicated to the presentation of the simulation and the analysis of results, and we close the paper with concluding remarks.

\section{The Methodology and Model}

A CGE model offers an analytical framework in which the economy is represented as a complete system of interdependent components. All economic agents, that is, households, firms, government, and the external sectors are all related by transactions on the markets and the price system. The model captures the fact that an economic shock has subsequent effects on the entire economy, which is not the case in a partial equilibrium framework. Hence, the CGE model captures the feedback effects (indirect effects) of various policy simulations. For example, if the government increases its spending in public infrastructure, the CGE model enables us to take into account the direct effect of the expenditures on the economy, such as the increase in the GDP of the sectors involved, but also the fact that this stimulation of the GDP will increase government fiscal revenues and will modify the remuneration of production factors [26]. The CGE model provides a way to analyze many types of problems, but is primarily used to simulate changes in taxation in a broad sense. Changes to a direct or indirect tax, a tax credit, a customs tariff, or a transfer can be simulated using a CGE model, and their effects on the economy at large, as well as agents and sectors, can be analyzed [26].

The other advantage of our model compared with the Adam-Bevan model is the richer presentation of production sectors. We make reference to our model instead of models since the specification is the same for each country. The 
country models only differ in the structural parameters calibrated on the respective social accounting matrix of each country.

In their study, Adam and Bevan explicitly introduce a competing import sector, an export sector, and a nontradable sector. Although this is an illustrative approach, we see from most disaggregated SAMs in Africa that few sectors are pure tradable or nontradable. They have instead variable degrees of openness to trade. Generally, the construction sector is nontradable, and even the agricultural sector cannot be described as either fully tradable or nontradable. We observe some export in subsistence agriculture in most African countries. In some of them, the proportion of exports on total production can be relatively large. For export crops, the rate can also be quite variable. The service sector sees a fair amount of differences from one country to the other. By using this decomposition instead of that used by Adam and Bevan, we anticipate that the Dutch disease might not be quite as virulent as forecast.

The CGE model presented here has the advantage of being fully coherent. All accounts must be balanced. This model will also allow us to identify the winners and losers of the different scenarios to be analyzed, simulate various fiscal policies to fund the investment, and provide a comparative analysis of winners and losers. With disaggregated production sectors in seven sectors, with the exception of Senegal and Benin for which some sectors were not available in the original social accounting matrix.

We will be able to highlight not only the winners and losers on this front but also the gainers and losers from the agent's end. Will households be favored over firms? And so forth. We will use the following seven sectors in all models: food crop agriculture, export agriculture, mining and oil, manufacturing, construction, private services, and public services.

We will be able to provide a comparative analysis of the countries and illustrate the importance or nonimportance of the structural differences between six African countries. By using the same behavioral assumptions, the same externality parameters, and the same macroeconomic closure rules the modeler is able to isolate the structural effects in the different countries. The selected countries have disparate economic structures, so it is possible that these will provide insightful insights.

We will also be able to compare funding options for infrastructure investment in terms of distributional impact in addition to the effects in real exchange rates and efficiency. This is important to help select the most efficient mode and to maximize the positive impact of scaling up infrastructure. Sensitivity analyses will be done not only on the general level of externalities but also on the sectoral differences of these externalities. Moreover, we will simulate different levels of infrastructure investment to get a sense of realistic goals.

The choice of using a static model is guided by the fact that in two previous papers using recursive dynamic CGE models to perform a comparative analysis of funding schemes to scale up infrastructure, the ranking of the funding options is the same after the first run (equivalent to a static model) compared to the end of the resolution. Hence, the ranking of funding scheme in Bayoudh [21] and in Boccanfuso et al. [22] is robust to this choice. The second reason behind this choice is the volume of simulations performed. A recursive dynamic CGE model produces a volume of results that would make it difficult to present synthetic and compact results.

The basic elements of the model are drawn from model EXTER of Decaluwé et al. [26]; we adjusted it in order to introduce infrastructure externalities. The objective was to introduce a function with a sector-specific elasticity for infrastructure investment. Toward this end, we prepared the model to consider four types of investment: road infrastructure, health, education, and telecom.

Production is determined by nested structure: total production of the branch (XS) comprises fixed valueadded shares (VA) and intermediate consumptions (CI), as is generally assumed in CGE modeling. The relationship determining the level of VA is a Cobb-Douglas function between composite labor (LD) and capital (KD). This valueadded function is multiplied by the externality parameter to be defined below. Producers minimize their cost of producing VA subject to the production function (CobbDouglas). Optimal labor-demand equations are derived from this minimization process. We have assumed that capital is partly fixed among sectors because after a policy shock in Africa, it is difficult in the short to medium term to convert capital for use in a new production sector. Intermediate consumptions have been modeled as fixed shares from the input/output ratios calculated on the basis of SAM. This modeling is typical.

We also postulate assumptions reflecting small open economies. In this context, world prices of imports and exports are exogenous. We posit the Armington hypothesis [27] for import demand whereby domestic consumers can substitute domestically produced goods with imports (imperfectly) by relying on a sector-specific elasticity of substitution. In sectors where local consumers are indifferent to consuming imported goods versus local goods, one sees high elasticity of substitution and, inversely, a small elasticity of substitution, where consumers prefer one good versus the other. A high elasticity in one sector implies that a change in relative price between the locally produced good (competing with the imported good) and the imported good will have a strong substitution effect. For example, if the price of the locally produced good increases compared with the price of the imported good, local consumers will substitute the imported good. If the elasticity of substitution is low, this same change in relative price will have only a slight substitution effect. The elasticity of substitution depends inter alia on differentiation between the goods and on the preference of local consumers. The relative price of the two goods is the other determinant of the ratio of demand between imported goods versus local goods. On the export side, producers can sell the goods on the local market or export their production; they are influenced by relative prices in each market and by their elasticity when the good is transformed for one or the other market.

The different agents' income equations are consistent with the structure presented in SAM. In this model, factor 
allocations are exogenous while factor payments are endogenous. Because capital is fixed by sector, we have six capital payments and one wage. Dividends paid to households are also endogenous and depend on a firm's income after taxes. The private firm's income is the balance of capital remuneration not paid to households, to which must be added government subsidies and transfers from the rest of the world. Government revenue comprises production taxes, customs duties, household, and private firm taxes as well as transfers from the rest of the world (budgetary assistance). The government spends its budget on consumption of public goods, transfers to households, subsidies to private firms, and transfers to the rest of the world and saving.

The demand function of households is derived from a utility-maximization process (Cobb-Douglas utility function), which leads to demand functions that are fixed-value share for each goods. Investment demand is decomposed in private investment made by households, the rest of the world, and firm and public investment by government savings. The investment demand is also specified with a fixed-value share function; we already described the demand for intermediate goods, which are fixed volume shares based on input-output matrix shares.

The price equations are quite standard. We have used the GDP deflator as a price index, and as stated earlier, international prices (imports and exports) are exogenous; accordingly, the country has no control over the prices applied to the world market.

The key assumptions of this model rely on the infrastructure spending, positive externalities of public infrastructure, and the budget constraint of the government. Hence, it is important to look at the specificities of the model used in the paper. We can first look at the government income sources (1). The government draws its revenues from indirect taxes on output $(\mathrm{Ti})$, direct taxes on household $(T d)$ and firms (Tde), and import duties (Tim). This equation is important since government will raise taxes to fund new infrastructure in some scenarios as follows:

$$
Y g=\sum_{i m} \operatorname{Tim}_{i m}+T d+T d e+\sum_{m} T i_{m}+\operatorname{Trg}+T e g+T g m
$$

The other sources of income are transfers from other agents, namely, the households (Tgm), the firms (Teg), and the rest of the world ( $\mathrm{Trg})$. These transfers can be negative or positive depending on the observed data of the country. The rest of the world transfers mainly comprise foreign aid to Africa. This source of funding will be used to fund infrastructure investments in one scenario. This first equation (1) does not provide the full picture because the investment will also be linked to government expenditure for operation and maintenance. The next equation (2) is the budget constraint for the government, which will spend part of its income $(Y g)$ on public services or expenditure $(G)$ and the other part on government savings $(S g)$, which will be used entirely to fund public investment on infrastructure as

$$
S g=Y g-G
$$

At this point, the closure rule used to balance this budget constraint will be key for our analysis. The closure rule consists in determining the variable of adjustment to reach an investment objective and hence the government savings will be exogenous.

We introduce an additional assumption that percentage increases in public infrastructure investment will generate higher operation and maintenance costs. Hence, the level of government expenditure will be a function of its original expenditure $(G o)$ plus the operation and maintenance of the new infrastructure as shown in (3)

$$
G=G o+\omega(\text { Itp }- \text { Itpo })
$$

Since empirical studies have shown that the new public infrastructure generates higher operation and maintenance costs, which varies by region and type of infrastructure investment. Hence the last expression in the equation reflects these new operation and maintenance cost computed with the increase in public investment (Itp - Itpo) and multiplying by $\omega$, which is the ratio of the maintenance cost over investment expenditure. We used the Fay and Yepes [28] figures to calibrate the $\omega$ parameter. The tables are figures computed from expected annual investments needs for 2005-2010 in Sub-Saharan Africa from Fay and Yepes [28]. We simply computed that ratio between investment needs and maintenance costs. See Table 1.

As we fix, or establish, investment objectives, the public investment (Itp) will be exogenous; implicitly, the government savings will also be exogenous given the identity of (4) as

$$
I t p=S g
$$

Given these assumptions, only one element can be adjusted so as to balance out the government budget constraint (2). The only variable we can use to adjust the budget constraint is the government income $\mathrm{Yg}$. As this variable is not free in the model (it is determined by the income generated from all sources of income), one variable of this equation will need to be rendered endogenous. One option would be to leave the $\operatorname{Tr} g$ endogenous, which would mean the objectives for public investment will be met by more foreign aid. The other option would be to endogenize one of the tax rates (household income tax, firms' income tax, production tax, or import duties). An intermediate option that could be simulated is to assume an exogenous rise in foreign aid ( $\mathrm{Trg}$ ) and let an internal tax rate adjust for the rest of the funds needed to meet the public investment objectives.

The externality (5) is the other important element in the model. This equation captures the link between infrastructure and private sector productivity gains. For this, we draw on the vast literature linking public infrastructure to private sector factor productivity, such as that modeled by Dumont and Mesplé-Somps [29] in a CGE context, although our externality function does not use the private investment. 
As in Savard [20], the function defining the externality is defined with the following function:

$$
\theta_{i}=\left(\frac{I t p}{I t p o}\right)^{\xi_{i}}
$$

where $\theta_{i}$ is the externality or sectoral productivity effect, which is a function of the ratio of new public investment (Itp) over past public investment (Itpo) with a sector-specific elasticity $\left(\xi_{i}\right)$. The values for this parameter were drawn from Harchaoui and Tarkhani [30] who estimated externalities by sector for Canada. Since these values were estimated for a developed country, and the literature reveals decreasing returns to public infrastructure, the values used can be considered as conservative with respect to this literature. See the appendix for specific parameter values. Given that parameters are below 1 , the returns to public infrastructure are positive but the growth occurs at the decreasing rate. $\partial \theta / \partial K G>0, \partial^{2} \theta / \partial K G^{2}<0$. We do not model direct private sector eviction effect tied to increased public investment. The externality of public infrastructure investment produces an increase in total factor productivity. This link to the value added $(\mathrm{Va})$ is taken into account in the Cobb-Douglas function of the following equation:

$$
\mathrm{Va}_{m}=\theta_{i} A_{m} \operatorname{Ld}_{m}^{\alpha m} \mathrm{Kd}_{m}{ }^{1-\alpha_{m}},
$$

where $A$ is the scale parameter, $\mathrm{Ld}$, the labor demand, $\mathrm{Kd}$, the capital demand, and $\alpha$ the Cobb-Douglas parameter. Hence, an increase in $\theta_{i}$ represents in Hicks's neutral productivity improvement, like the one modeled in Yeaple and Golub [31]. This formulation is also commonly used in the literature estimating parameters of the externalities of public infrastructure on total factor productivity such as Ashauer [2], Munnell [3], Bajo-Rubio and Sosvilla-Rivero [32], Gramlich [33], and Dessus and Herrera [34] among others. This literature also reveals that returns to infrastructure is higher in less developed countries and the returns generally decrease as the level of infrastructure increases. This is reflected in our formulation of the externalities (5) and (6). With this formulation, the infrastructure investment can act as a source of comparative advantage because the function is sector specific. It is important to highlight that our formulation of the link between new investments in infrastructure and sectoral productivity does not exclude externalities for past investments in infrastructure. This link is captured and calibrated in the $A_{m}$ parameter of (6). In fact, the combination of $\theta_{i}$ and $A_{m}$ is equivalent to decomposing the standard scale parameter of the Cobb-Douglas function. This formulation is also used in Savard [20] and Savard [35].

Model equilibrium conditions are also standard. The commodity market is balanced by adjusting the market price of each commodity. The labor market balances out by adjusting the nominal wage. One should also note that labor supply is fixed and that there is no unemployment. This does not mean that we assume that there is zero unemployment in the countries but simply that unemployment is exogenous to the model. The current account balance is fixed; accordingly, the nominal exchange rate varies to allow the real exchange
TABLE 1: Value for $\omega$.

\begin{tabular}{ll}
\hline \multicolumn{2}{c}{$\omega$ parameters } \\
\hline Road & 0.84 \\
Telecom & 0.74 \\
Electricity & 0.90 \\
\hline
\end{tabular}

rate to clear the current account balance. The same archetype will be applied to the six other countries. Minor adjustments will be needed to account for the different fiscal structures and the agents' transfer matrix.

Given our assumption, we consider that we model a medium run to long run perspective. In this context, the economies will have time to capture the benefits of the new infrastructure and equilibrium will be achieved in the different markets we model.

\section{Presentation of the Economies and SAM}

Geography, demographics, and economic structure were all considered in selecting the six African countries we analyzed. These sets were chosen not only to maximize country coverage but also to ensure that the various economic realities were captured.

The analysis focuses on a number of items inter alia, the differential sectoral effects of the investments, budgetary impacts, welfare changes for all agents of the model (households, government, firms, and rest of the world), and other macro and sectoral variables of the model. See Table 2, which shows the number of sectors and the reference year for each SAM. Each SAM had to be aggregated to obtain a format that was close to uniform. See Table 3.

In this section, we highlight the structural differences and similarities of the economies studied. It is important to focus on structural issues, as all the models constructed exhibit the same hypotheses and behavioral parameters. The only differences among the applications stem from the specific structure of the social accounting matrices (SAM), which reflect the economic structures of the countries selected. We do not present the complete SAM for the economies but focus instead on a few structural characteristics. As in all CGE models, the labor/capital ratio of the production sectors always plays an important role in the results obtained from policy simulations. Other ratios of importance are the weight of the sectors in the GDP, the export/output ratio, and the import/total consumption ratio.

Let us first look at the weight of the sectors in the total GDP of the different countries. See Table 4.

This table tells us that the economies of Senegal (23 percent) and Cameroon (24 percent) rely less on agriculture. The other countries range from 37 percent (for Mali) and 45 percent for Uganda. At 7 percent each, Benin and Cameroon have the smallest export agriculture sectors; Tanzania has the largest at 17 percent. Mining and gas is an important sector. The oil sector is important for Cameroon, while the mining sector (gold) is very important for the Malian economy (11 percent). The industrial sector is relatively small in all countries, ranging from 9 percent in Mali and 20 percent 
TABLE 2: Presentation of the selected countries.

\begin{tabular}{|c|c|c|c|c|c|c|}
\hline Countries & Size $\left(\mathrm{km}^{2}\right)$ & Population (million) & GDP/capita & Main production & Main export & Geography \\
\hline Tanzania & 945.000 & 37 & $700 \$$ & Agric & Agric & Coastal \\
\hline Uganda & 236.000 & 27.2 & $1500 \$$ & Agri. Serv & Coffee & Landlocked \\
\hline Senegal & 196.000 & 11.1 & $1700 \$$ & Serv & Peanut/fish & Coastal \\
\hline Mali & 1.240 .000 & 12.3 & $900 \$$ & Agric & Cotton. gold & Landlocked \\
\hline Benin & 112.000 & 7.4 & $1200 \$$ & Agric & Cotton & Coastal \\
\hline Cameroon & 474.000 & 16.3 & $1900 \$$ & Agric. oil & Coffee. oil & Coastal \\
\hline
\end{tabular}

TABLE 3: Level of disaggregation and reference year of the selected countries.

\begin{tabular}{lcc}
\hline Countries & Number of sectors & Reference year \\
\hline Tanzania & 7 & 2000 \\
Uganda & 7 & 1999 \\
Senegal & 6 & 1996 \\
Mali & 7 & 2001 \\
Benin & 5 & 2000 \\
Cameroon & 7 & 2000 \\
\hline
\end{tabular}

in Cameroon. The construction sector accounts only for 2 percent of the Cameroonian economy, whereas it represents 10 percent for Tanzania. Other countries fall between these two extremes. The largest country differences are found in private services, where we see half the Senegalese economy (47 percent) relies on services and Tanzania at only 22 percent. Public services are quite similar, with most countries around 8 percent; the two extremes being Cameroon with 10 percent on the higher end and Uganda on the lower end at 4 percent.

In Table 5, we present the labor/capital ratio for each country. This is important because pressure on factor market will benefit labor- or capital-intensive sectors depending on the policy simulated. Hence, these ratios will be informative for the sectoral analysis provided below.

Before analyzing this table, we should highlight the fact that a different methodological approach is at the root of important differences noted in the table. According to common practice, national accounts place the small household farmers' surplus in the capital account. In the modeling world, some believe this should not be maintained in a SAM and be placed instead in the labor payment account. Without complete information on each SAM, we did not modify them. But some modelers have modified these numbers, namely, in Cameroon, Tanzania, and probably in Uganda. In the three other countries, the modelers have probably kept the SAM as the input-output table. This explains the large differences for the two agricultural sectors. One tendency to emerge is that, with the exception of Senegal, crop agriculture is more labor intensive than export agriculture. In Senegal, export agriculture comprises the very labor-intensive groundnut. The mining sector is very capital intensive, especially the oil sector in Cameroon and the least intensive in Uganda (28 percent). For the industries, we observe differences between Tanzania, whose very laborintensive industry has a ratio above 1 (1.08), and Benin, with the least intensive (cotton) at a ratio of 0.2. Construction is also labor intensive, except in Senegal and Tanzania.

The next structural feature is the exports on total output by sector, which is presented in Table 6 .

The relatively similar ratio for the export agriculture sectors is an interesting feature of this table. But many products undergo a first round of transformation by the industrial sector prior to export. The other surprising figure is Tanzania's 41 percent for the construction sector. Some countries export a lot of their industrial production, such as Senegal (32 percent) and Uganda (23 percent), but others very little: Mali at 0.2 percent and Tanzania at 2 percent. We also see large disparities in the export of private servicesranging from 38 percent in Benin to 4 percent in Tanzania. The most important export sector for Tanzania and Mali in relative terms is export agriculture, for Uganda and Senegal, it is industry. Benin's most important export sector is private services, and, finally, the oil and mining sector is Cameroon's the most important export sector.

The final structural feature presented here is imported goods over total national consumption, which includes final household and government consumption, intermediate inputs to the sectors, and demand for investments goods. The ratios are presented in Table 7.

The agricultural sectors contain interesting features. Senegal is the only significant importer of crop agriculture (25 percent), where all other countries are below 5 percent. Regarding export agriculture, four countries import some goods likely destined for the industrial sector. Gas and mining is an imported good in Cameroon, Tanzania, and Uganda. With the exception of Cameroon (22 percent), all countries have high import ratios for industrial goods. Once again, Tanzania (at 32 percent) imports a lot of construction goods or services, especially in comparison with figures that are close to zero in the other countries. The imports of private services range from 3 percent in Tanzania to 10 percent for Uganda.

In light of the figures, and so forth, we can expect differentiated effects in our simulations. The other structural features not presented here but nevertheless with a role to play include public investment, household consumption, and the fiscal structure of the governments.

\section{The Simulations}

For our analysis, we perform increase in public investment in infrastructure. The scale of the increase is $20 \%$ with an 
TABLE 4: Weight of the productive sectors in total GDP.

\begin{tabular}{lccccccc}
\hline & Crop agriculture & Export agriculture & Mining and gas & Industries & Construction & Private services & Public services \\
\hline Benin & 0.35 & 0.07 & N/A & 0.14 & N/A & 0.36 & 0.07 \\
Cameroon & 0.17 & 0.07 & 0.10 & 0.20 & 0.02 & 0.35 & 0.10 \\
Mali & 0.21 & 0.16 & 0.11 & 0.09 & 0.06 & 0.28 & 0.07 \\
Senegal & 0.12 & 0.11 & N/A & 0.17 & 0.04 & 0.47 & 0.09 \\
Tanzania & 0.26 & 0.17 & 0.02 & 0.16 & 0.10 & 0.22 & 0.06 \\
Uganda & 0.32 & 0.13 & 0.0007 & 0.11 & 0.08 & 0.04 \\
\hline
\end{tabular}

TABLE 5: Labor/capital ratios by sector and countries.

\begin{tabular}{lccccccc}
\hline & Crop agriculture & Export agriculture & Mining and gas & Industries & Construction & Private services & Public services \\
\hline Benin & 0.03 & 0.03 & N/A & 0.20 & N/A & 0.20 & 1.00 \\
Cameroon & 3.69 & 1.01 & 0.03 & 0.66 & 5.09 & 0.98 & 1.00 \\
Mali & 0.13 & 0.07 & 0.11 & 0.64 & 2.38 & 0.30 & 1,00 \\
Senegal & 0.02 & 0.64 & N/A & 0.32 & 0.21 & 0.21 & 1.00 \\
Tanzania & 2.83 & 1.74 & 0.07 & 1.08 & 0.59 & 0.53 & 1.00 \\
Uganda & 1.07 & 0.94 & 0.28 & 0.88 & 1.43 & 1.42 & 1.00 \\
\hline
\end{tabular}

exception that will be presented hereafter. Our comparative analysis is done on three dimensions. First, we have country-specific models, second we compared different types of infrastructure, and third we analyze different funding schemes to scale up infrastructure. We have already presented the six countries in the previous section. As for the types of infrastructure, we have four types: (1) baseline nonproductive investments, (2) road infrastructure, (3) electricity, and (4) telecom infrastructure. We then perform simulations for the comparative analysis of funding schemes. We have five funding schemes for each set of productive investments and four funding schemes for the unproductive investments. It is important to reiterate that the main objective of the paper is to verify how important the structure of the African economies is in the type of conclusion that authors have obtained with impact analysis of scaling up public infrastructure in Africa (see results of [23], Estache et al. [7], and Bayoudh [21]. The objective is not to see how strong growth is and the level of the Dutch disease. Hence, it is not critical to perform sensitivity analysis with our behavioural and externality elasticities as it would be the case if your objective was the measure growth level in each country. Moreover, with over 100 simulations performed for this paper, performing sensitivity analysis would require running an unreasonable amount of simulations. In the first funding scheme, we lessen other public expenditure to fund the investments and their maintenance. Productive externalities will contribute to increased economic activity, which will increase government revenues. It is important to highlight this fact. Hence, the funding requirements are not equal to the investment and operation costs. In the second funding option, we increase the value-added tax in the economy. In the third, we increase import duties. In the fourth, foreign aid is the source of funding. The final option is to increase income taxes to provide the required funds. This comparative analysis allows us to highlight the most efficient funding mechanism and to explore the effect on different macroeconomic and sectoral variables. Because these simulations were performed on six country models, we produced 114 simulations. The complete results can be obtained upon request to authors. For the impact analysis, we have selected two funding schemes for each type of investments. For the impact analysis of this paper, we have selected two funding schemes for each type of investments. We present the simulations in a synthetic form in Table 8.

\section{Impact Analysis of the Scenarios}

We concentrate on the macroeconomic variables to simplify the presentation, and we highlight the main sectoral effects for one funding option for each type of investment. We provide a comparative analysis among the countries for two funding options affecting the four different investment strategies. We therefore will analyze in more detail 8 of the 19 scenarios for six countries. This approach facilitates comparative analyses of the investment strategies and the efficiency of different funding modalities. We begin by presenting the unproductive investment option as the baseline scenario. In each productive investment scenario, we will observe an increase in GDP - a direct consequence of our externality hypothesis. Because we have assumed that our total endowment of productive factors is exogenous, growth in GDP is generated directly by the externalities of our public investment in infrastructure. The relative importance of this increase between simulation sets is directly determined by the externality elasticities we selected and the relative importance of the economic sectors. When looking at results, it is important to keep in mind that current account balance is fixed in the models. The current account is balanced by an adjustment of the real exchange rate. In our table we present the nominal exchange rate but the two are the same since the 
TABLE 6: Export/output ratios by sector and countries.

\begin{tabular}{lcccccc}
\hline & Crop agriculture & Export agriculture & Mining and gas & Industries & Construction & Private services \\
\hline Benin & 0.06 & 0.08 & N/A & 0.18 & N/A & 0.38 \\
Cameroon & 0.01 & 0.12 & 0.95 & 0.15 & 0.00 & 0.07 \\
Mali & 0.04 & 0.33 & 1.00 & 0.002 & 0.00 & 0.09 \\
Senegal & 0.01 & 0.06 & N/A & 0.32 & 0.01 & 0.41 \\
Tanzania & 0.03 & 0.15 & 0.09 & 0.02 & 0.00 & 0.04 \\
Uganda & 0.01 & 0.04 & 0.00 & 0.23 & 0.06 \\
\hline
\end{tabular}

TABLE 7: Import/total demand ratios by sector and countries.

\begin{tabular}{|c|c|c|c|c|c|c|}
\hline & Crop agriculture & Export agriculture & Mining and gas & Industries & Construction & Private services \\
\hline Benin & 0.05 & 0.00 & N/A & 0.27 & N/A & 0.03 \\
\hline Cameroon & 0.01 & 0.03 & 0.88 & 0.22 & 0.01 & 0.07 \\
\hline Mali & 0.04 & 0.09 & 0.00 & 0.61 & 0.00 & 0.06 \\
\hline Senegal & 0.25 & 0.04 & N/A & 0.39 & 0.00 & 0.08 \\
\hline Tanzania & 0.02 & 0.05 & 0.60 & 0.30 & 0.32 & 0.03 \\
\hline Uganda & 0.01 & 0.00 & 0.75 & 0.39 & 0.00 & 0.10 \\
\hline
\end{tabular}

TABle 8: Presentation of the simulation.

(1) Nonproductive investment
(a) VAT funding
(b) Import duties funding
(c) Foreign aid funding
(d) Income tax funding

(2) Roads
(a) Reduction in other public expenditure
(b) VAT funding
(c) Import duties funding
(d) Foreign aid funding
(e) Income tax funding

(3) Electricity
(a) Reduction in other public expenditure
(b) VAT funding
(c) Import duties funding
(d) Foreign aid funding
(e) Income tax funding

(4) Telecom
(a) Reduction in other public expenditure
(b) Reduction in other public expenditure
(c) VAT funding
(d) Import duties funding
(e) Foreign aid funding

price index is held fixe (being the numeraire in the model). So the variation in the nominal exchange rate is equivalent to the variation in the real exchange rate.

Before moving to the analysis, we highlight that, for Uganda, we have increased public investment by only 5 percent. We were constrained here given the high level of public investment for the reference period. Simulating a 20 percent increase was not possible for the foreign aid scenario. Given the nominal increase in size, it produced an excessive pressure on the nominal exchange rate.

5.1. The Investment in Nonproductive Infrastructure. We use this simulation as the baseline scenario, which can be interpreted as an investment in the construction of monuments, in the army (if the country is not in conflict), or other types of nonproductive investments by the government. One could also interpret these results as the ones obtained in a model where the externality assumption is not considered. We look at two funding options to increase the nonproductive public investment. The first is an increase in the value-added tax, and the second is an increase in import duties. Let us analyze the simulations for the six countries.

5.2. Investment Funded by the Value Added Tax. In this simulation, we increased the nonproductive public investment (investment that does not produce production externalities for other productive sectors); the increase in spending by the government is funded by a uniform increase of the effective value added tax. At the reference period, the value added tax (VAT) is not uniform and the differentiated structure remains after simulation. We apply a uniform tax increase so the percentage adjustment is the same for all sectorsif the tax rate in the sector is positive at the reference period. We hold exogenous the other public expenditure made by government but assume as was explained earlier that the new investment will require some new operational expenditure. Hence the 20 percent increase in government saving and the new public expenditure for operation cost of the new investment is funded by the increase in value added tax. In this simulation as in others, an important structural distinction between the countries is the initial nominal public investment. If this is very low at the reference 
period, the 20 percent increase will be smaller in nominal terms than in the countries where the reference period public investment is very large. Let us first look at the macro results for all countries in Table 9.

The first observation is that this option seems to favor households over firms, in all countries because wages increase more than the average rental rate of capital. The increase in government income derives from the increased VAT to fund new investment. As the investment in public expenditure does not produce externalities, the government does not benefit from increased income from economic growth. Therefore, the rise in income can be attributed almost exclusively to the VAT increase to fund the operation costs of new public investments. For comparative purposes, this will be useful in the following scenarios to see how growth influences government income. As we have said, the other common feature is that the simulation produces an increase in wages. This comes from the fact that public services must grow to meet the operational needs created by new investment. In addition, this sector places more pressure on the labor market than on the capital market.

Comparing the impact on the aggregate representative household income, we note an increase for all countries with the strongest impact for Senegal and Cameroon. This comes from the fact that the increase in wage payments is strongest for these two countries. The steepest drop in firm income is also observed in these two countries. The total private investment falls in all countries (eviction of private investment for the public investment) with the exception of Benin; the growth in private investment in Benin is relatively small (+0.04 percent).

5.2.1. Investment Funded by Import Duties. For the import duties funding option, we will analyze both the macro and sectoral results. In this case, we let the import duties adjust uniformly from the reference situation where we observed distorted effective rates. The macro results are presented in Table 10 .

At the macro level, the results largely resemble the VAT-funded scenario. As seen in the previous section, the government income effect is by definition the same. The negative effect is stronger for all countries on the private investment. The largest difference between the two funding options for this variable is observed for Uganda, which falls from -0.16 percent to -0.85 percent. See Table 11 .

A common effect across the countries analyzed (and observed in the four investment scenarios) is the stronger increases of output for public services compared with other productive sectors. Value added and output exhibit the same variation changes as they are linked with a fixed share parameter from the Leontief hypothesis.

This occurs by definition given the operational cost constraint and the construction sector, which benefits directly from the public investment as the sector directly involved in constructing the infrastructures. Given the constraint of factors in the model, the increased output of these two sectors is compensated by a reduction of output for all other sectors and this is valid in all countries. Because we do not have investment externalities in this scenario, labor is taken from these other sectors for the construction and public services sector to increase production. We only observe one exception of this situation and it is for the mining and gas sector in Uganda, which increases its output slightly by 0.06 percent. That sector in Uganda is very small $(0.07$ percent of the GDP) and capital intensive. Given the pressure on the labor market, which generates wage increases in all countries, the more labor-intensive sectors are in penalized. No clear tendency is observed in the most negatively affected sector. In fact (with the exception of the industrial sector in Senegal and Uganda), a different sector is affected in each country. In Benin, it is the private services, crop agriculture in Cameroon, in Mali it is mining and gas, and in Tanzania crop agriculture. As a consequence, the policy and funding schemes do not produce uniform sectoral results among the countries. We can therefore conclude that the structural effects of the economies dominate the behavioral effects in this respect.

As for the price effects, our increase in import duties causes most prices to rise in most countries. But the dominating effect on prices remains on the demand side for the construction sector. Given the increase in demand for construction good via the increase in public investment, we observe the strongest price increase (or second biggest) for this sector in all countries. In general, the crop agriculture and private services sector seem to be the least affected in most countries.

As mentioned above, pressure on the factor markets focuses on labor, so we observe rising wages in all countries. This implies that capital becomes relatively more abundant and its prices (the borrowing rate) decrease in most sectors and for all countries. We observe a few exceptions to this trend, such as the industry in Benin and Mali and mining and gas in Uganda. The capital payment rate in the construction sector increases in all countries once again given the strong pressure from the demand side.

5.3. The Investment in Road Infrastructure. Moving on to the road investment option, we are now analyzing scenarios with production externalities. The first systematic difference with the baseline scenario is the fact that we will now observe increases in GDP generated by the sector specific externalities associated with road investments. This will add some sectoral differences compared to the baseline simulations.

5.3.1. Investment Funded by Foreign Aid. In this scenario, we assume that the new investment is funded by a grant from a foreign donor. Table 12 presents the macro results of this investment option and funding scheme.

The first comment we can make on these results is the differences observed for the impact on GDP between countries. In Benin, the GDP increases by only 0.69 percent where an increase of 1.03 percent is observed for Senegal and 0.84 percent for Mali. As we have mentioned the investment change simulated in Uganda we one quarter of what was performed in other countries. Hence, the impact on the GDP for Uganda is around one quarter of what we observed for 
TABLE 9: Macroeconomic results for nonproductive investments, VAT funded (values in table are \% variations of variables with respect to reference period).

\begin{tabular}{|c|c|c|c|c|c|c|c|}
\hline \multirow{2}{*}{ Variable } & \multirow{2}{*}{ Definition } & \multicolumn{6}{|c|}{ Nonproductive investment (VAT funded) } \\
\hline & & Benin & Mali & Senegal & Tanzania & Uganda & Cameroon \\
\hline$Y m$ & Aggregate household income & 0.09 & 0.06 & 0.29 & 0.02 & 0.02 & 0.25 \\
\hline$E V$ & Equivalent variation & 0.09 & 0.06 & 0.26 & 0.02 & 0.02 & 0.23 \\
\hline$s$ & Wage & 4.42 & 0.49 & 1.29 & 0.07 & 0.11 & 0.56 \\
\hline$y g$ & Government income & 14.70 & 3.19 & 5.90 & 5.44 & 3.14 & 6.36 \\
\hline ye & Firms income & -0.71 & -0.18 & -0.45 & -0.08 & -0.13 & -0.64 \\
\hline$g$ & Total government expenditure & 11.96 & 1.73 & 5.38 & 3.52 & 2.49 & 7.27 \\
\hline It & Total private investment & 0.04 & -0.17 & -0.45 & -0.13 & -0.16 & -0.86 \\
\hline$e$ & Nominal exchange rate & 1.69 & 0.03 & 0.07 & 0.02 & -0.12 & 0.35 \\
\hline GDP & GDP & 0.02 & 0.00 & 0.01 & 0.00 & 0.00 & 0.00 \\
\hline
\end{tabular}

TABLE 10: Macroeconomic results for nonproductive investments, import duties funded (values in table are \% variations of variables with respect to reference period).

\begin{tabular}{|c|c|c|c|c|c|c|c|}
\hline \multirow{2}{*}{ Variables } & \multirow{2}{*}{ Definition } & \multicolumn{6}{|c|}{ Nonproductive investment (import duties funded) } \\
\hline & & Benin & Mali & Senegal & Tanzania & Uganda & Cameroon \\
\hline$Y m$ & Aggregate household income & 0.10 & 0.08 & 0.29 & 0.04 & 0.02 & 0.35 \\
\hline$E V$ & Equivalent variation & 0.09 & 0.08 & 0.26 & 0.04 & 0.02 & 0.32 \\
\hline$s$ & Wage & 4.81 & 0.72 & 1.27 & 0.10 & 0.11 & 0.78 \\
\hline$y g$ & Government income & 14.70 & 3.19 & 5.90 & 5.44 & 3.14 & 6.36 \\
\hline ye & Firms income & -0.77 & -0.26 & -0.44 & -0.13 & -0.14 & -0.89 \\
\hline$g$ & Total government expenditure & 11.96 & 1.73 & 5.38 & 3.52 & 2.49 & 7.27 \\
\hline It & Total private investment & -0.18 & -0.25 & -0.65 & -0.52 & -0.85 & -1.16 \\
\hline$e$ & Nominal exchange rate & -1.20 & -0.70 & -1.38 & -1.00 & -2.39 & -1.92 \\
\hline GDP & GDP & 0.01 & 0.00 & 0.01 & 0.00 & 0.00 & 0.00 \\
\hline
\end{tabular}

TABLE 11: Sectoral results for nonproductive investments, import duties funded (values in table are \% variations of variables with respect to reference period).

\begin{tabular}{|c|c|c|c|c|c|c|c|}
\hline \multirow{2}{*}{ Variable } & \multirow{2}{*}{ Sector } & \multicolumn{6}{|c|}{ Nonproductive investment (import duties) } \\
\hline & & Benin & Mali & Senegal & Tanzania & Uganda & Cameroon \\
\hline \multirow{7}{*}{$V a$ (value added or output) } & Crop agriculture & -0.14 & -0.08 & -0.03 & -0.14 & -0.08 & -0.87 \\
\hline & Export agriculture & -0.19 & -0.07 & -0.95 & -0.38 & -0.27 & -0.60 \\
\hline & Mining and gas & & -0.25 & & -0.04 & 0.06 & -0.10 \\
\hline & Industries & -0.65 & -0.15 & -1.08 & -0.25 & -0.64 & -0.60 \\
\hline & Construction & & 0.47 & 1.88 & 0.17 & 1.05 & 5.24 \\
\hline & Private services & -1.10 & -0.14 & -0.35 & -0.09 & -0.12 & -0.52 \\
\hline & Public services & 7.60 & 1.09 & 4.24 & 2.32 & 2.27 & 4.19 \\
\hline \multirow{7}{*}{$p q$ (market prices) } & Crop agriculture & 0.25 & 0.18 & -0.08 & 0.14 & 0.07 & 0.74 \\
\hline & Export agriculture & -1.08 & 0.00 & 0.38 & 0.47 & -0.04 & 1.67 \\
\hline & Mining and gas & & -0.31 & & 0.23 & 1.71 & 0.71 \\
\hline & Industries & 3.38 & 0.65 & 1.69 & 0.54 & 0.02 & 2.65 \\
\hline & Construction & & 0.65 & 6.07 & 0.60 & 0.49 & 2.24 \\
\hline & Private services & 0.80 & 0.35 & 0.28 & 0.10 & 0.15 & 0.73 \\
\hline & Public services & 4.05 & 0.61 & 1.09 & 0.18 & 0.21 & 1.13 \\
\hline \multirow{6}{*}{$r$ Borrowing rate of capital } & Crop agriculture & -0.49 & 0.01 & -0.13 & -0.09 & -0.03 & -0.34 \\
\hline & Export agriculture & -2.42 & -0.44 & -1.19 & -0.49 & -0.45 & -0.42 \\
\hline & Mining and gas & & -1.83 & & -0.51 & 0.40 & -2.84 \\
\hline & Industries & 0.86 & 0.32 & -3.17 & -0.37 & -1.26 & -0.73 \\
\hline & Construction & & 1.39 & 12.88 & 0.58 & 1.91 & 7.12 \\
\hline & Private services & -1.85 & 0.09 & -0.72 & -0.14 & -0.10 & -0.27 \\
\hline
\end{tabular}


TABLE 12: Macroeconomic results for road investments, funded by foreign aid (values in table are \% variations of variables with respect to reference period).

\begin{tabular}{lccccccc}
\hline \multirow{2}{*}{ Variables } & \multirow{2}{*}{ Definition } & \multicolumn{4}{c}{ Road (foreign aid funded) } \\
& & Benin & Mali & Senegal & Tanzania & Uganda & Cameroon \\
\hline$Y m$ & Aggregate household income & 0.74 & 0.87 & 1.01 & 0.55 & 0.21 & 1.07 \\
$E V$ & Equivalent variation & 0.75 & 0.89 & 1.00 & 0.55 & 0.25 & 1.12 \\
$s$ & Wage & 4.88 & 1.77 & 2.00 & 0.82 & 0.42 & 1.84 \\
$y g$ & Government income & 13.53 & 2.93 & 5.43 & 5.00 & 2.89 & 5.85 \\
$y e$ & Firms income & -0.12 & 0.51 & 0.69 & 0.80 & -0.05 & -0.62 \\
$g$ & Total government expenditure & 10.05 & 1.46 & 4.52 & 2.96 & 2.09 & 6.11 \\
$I t$ & Total private investment & 0.17 & 0.71 & 0.04 & 1.31 & -3.45 & -0.27 \\
$e$ & Nominal exchange rate & -4.85 & -2.25 & -4.24 & -1.61 & -11.68 & -6.31 \\
$G D P$ & GDP & 0.69 & 0.84 & 1.03 & 0.81 & 0.21 & 0.70 \\
\hline
\end{tabular}

Tanzania and Mali. Once again, the differences are not major but considering that since behavioral equations and external elasticities are the same, the differences originate from the sectoral structure of the GDP in the different countries. If a sector is larger and it receives a smaller externality, the country will benefit less than where the larger sector benefits the most from road investment increases. Looking at the equivalent variation, we note that the strongest effect is in Cameroon, followed by Senegal and the weakest positive effect is in Tanzania. In some countries, the positive impact on households (equivalent variation) is similar to the change in GDP such as Senegal and quite different in others, namely, in Cameroon and Tanzania. Contrary to the baseline scenario, we do not systematically have the households being the winners versus the firms. It is the case for 5 of the countries but in Tanzania the firms are the biggest winners. Moreover, in the baseline scenario, firms were losers in all countries and in this case, the firms increase their revenues in three countries and the ones where it decreases the reduction are smaller than in the baseline case. There are also relatively large differences for the change in wage, although it still increases in all countries. The increases in wage rate range from 0.42 percent in Uganda to 4.88 percent in Benin.

Given the better performance of the private firms as well as households, the economy generates more private saving and implicitly the private investment increases in four countries, decreasing only in Uganda and Cameroon. This funding option combined with our exogenous current account balance produced strong pressure on the nominal exchange rate. If fact, we could use the real exchange rate easily for our analysis as our price index is exogenous in the model and is fixed at 1 . Since we impose an inflow of funds and the current account balance (CAB) must remain constant, we will need to import more and export less to maintain the $\mathrm{CAB}$ constant. An appreciation of the nominal exchange rate will lead us to this result. Hence, we observe a decline in the nominal exchange rate in all countries. The importance in the reduction is strongly related to the relative importance of foreign aid needed to fund the road construction. This is the case for Uganda, where the nominal exchange rate diminishes by 11.7 percent. Tanzania has the weakest drop at 1.6 percent.
5.3.2. Investment Funded by a Reduction of Other Public Expenditure. We turn to the same road investment. This time, however, it is financed by reducing other public expenditure. For example, the government could curtail other services to fund the construction and operation of roads. We have assumed that other curtailed services do not produce externalities (positive or negative). Table 13 presents the macro results for this scenario.

The GDP effects are the same as with the previous scenario since the externalities produced are the same. For the households, however, we note weaker positive effects on equivalent variation in all the countries. The biggest reductions are found for Cameroon from 1.12 percent to 0.38 percent and Senegal from 1.0 percent to 0.5 percent. The other countries experience only slight decreases of the positive effect. Given the reduction in public services, a downward pressure on labor versus the previous simulation takes place, this reduces the positive effect on the wage in four countries and reverses the positive effect to a negative effect in Benin and Senegal. An interesting aspect compared to the previous simulation and the baseline case is that in all countries, the firms are clear winners compared to households. This situation also produced a positive effect on private investment which increases in all countries. Tanzania and Cameroon experience the largest increases in private investment with increases of 2.51 percent and 2.02 percent, respectively.

We also note that the effect on the nominal exchange rate is varied, with an appreciation in three countries (Mali, Senegal, and Cameroon) and depreciation in the three other (Benin, Tanzania, and Uganda). This is a consequence of the import and export structure in the different countries. The sectoral effects are presented in Table 14.

Our first observation in comparing these results with the baseline case is that all sectors increase output-the direct result of road investment externalities. As we cut other public services to fund the investment, this sector falls in all countries compared with increases for the baseline situation. To analyze the sectoral effects, we must bear in mind the road externality parameters (see the appendix). We should note that the mining, export agriculture, and construction sectors benefit the most. As other general equilibrium effects are at 
TABLE 13: Macro results of road investments, funded by reduction of public expenditure (values in table are \% variations of variables with respect to reference period).

\begin{tabular}{|c|c|c|c|c|c|c|c|}
\hline \multirow{2}{*}{ Variable } & \multirow{2}{*}{ Definition } & \multicolumn{6}{|c|}{ Road (funded by reduction of other public expenditure) } \\
\hline & & Benin & Mali & Senegal & Tanzania & Uganda & Cameroon \\
\hline$Y m$ & Aggregate household income & 0.60 & 0.76 & 0.51 & 0.45 & 0.16 & 0.38 \\
\hline$E V$ & Equivalent variation & 0.61 & 0.76 & 0.50 & 0.45 & 0.16 & 0.38 \\
\hline$s$ & Wage & -3.22 & 0.76 & -0.28 & 0.57 & 0.14 & 0.31 \\
\hline$y g$ & Government income & 1.77 & 0.61 & 0.84 & 0.87 & 0.21 & 0.69 \\
\hline ye & Firms income & 1.20 & 0.87 & 1.50 & 1.13 & 0.29 & 1.16 \\
\hline$g$ & Total government expenditure & -9.08 & -1.07 & -3.85 & -2.39 & -2.15 & -11.79 \\
\hline It & Total private investment & 0.79 & 1.08 & 1.43 & 2.51 & 0.44 & 2.02 \\
\hline$e$ & Nominal exchange rate & 1.10 & -0.61 & -0.46 & 0.57 & 0.23 & -0.27 \\
\hline GDP & GDP & 0.69 & 0.84 & 1.03 & 0.81 & 0.21 & 0.70 \\
\hline
\end{tabular}

TABLE 14: Sectoral results for road investments, import duties funded (values in table are \% variations of variables with respect to reference period).

\begin{tabular}{|c|c|c|c|c|c|c|c|}
\hline \multirow{2}{*}{ Variable } & \multirow{2}{*}{ Sector } & \multicolumn{6}{|c|}{ Road (reduction of other public expenditure) } \\
\hline & & Benin & Mali & Senegal & Tanzania & Uganda & Cameroon \\
\hline \multirow{7}{*}{$V a$ (value added or output) } & Crop agriculture & 1.03 & 0.92 & 0.95 & 0.83 & 0.22 & 1.34 \\
\hline & Export agriculture & 1.50 & 1.37 & 1.91 & 1.25 & 0.36 & 1.53 \\
\hline & Mining and gas & & 1.54 & & 1.52 & 0.09 & 1.59 \\
\hline & Industries & 1.75 & 0.83 & 1.75 & 0.82 & 0.35 & 1.18 \\
\hline & Construction & & 2.25 & 3.32 & 2.05 & 1.66 & 8.70 \\
\hline & Private services & 1.24 & 0.5 & 1.19 & 0.61 & -0.01 & 0.72 \\
\hline & Public services & -7.05 & -1.43 & -3.46 & -2.06 & -2.20 & -4.25 \\
\hline \multirow{7}{*}{$p q$ Market prices } & Crop agriculture & -0.02 & -0.12 & -0.24 & -0.30 & -0.11 & -0.36 \\
\hline & Export agriculture & 0.03 & -0.59 & -0.64 & -0.70 & -0.20 & -0.37 \\
\hline & Mining and gas & & -0.97 & & -0.05 & 0.18 & -0.28 \\
\hline & Industries & 0.89 & -0.36 & -0.73 & 0.19 & 0.07 & 0.10 \\
\hline & Construction & & 0.03 & 5.71 & 0.94 & 0.45 & 0.16 \\
\hline & Private services & -0.37 & 0.38 & -0.51 & 0.42 & -0.02 & 0.10 \\
\hline & Public services & -2.19 & 0.4 & -0.41 & 0.51 & 0.05 & 0.24 \\
\hline \multirow{6}{*}{$r$ Borrowing rate of capital } & Crop agriculture & 0.98 & 0.8 & 0.96 & 0.46 & 0.10 & 0.84 \\
\hline & Export agriculture & 1.43 & 0.71 & 1.06 & 0.38 & 0.14 & 0.61 \\
\hline & Mining and gas & & 0.55 & & -0.08 & -1.34 & 1.21 \\
\hline & Industries & 3.26 & 1.24 & 0.47 & 0.91 & 0.54 & 1.67 \\
\hline & Construction & & 2.53 & 16.23 & 3.40 & 2.51 & 9.51 \\
\hline & Private services & 1.34 & 0.97 & 0.72 & 1.02 & -0.08 & 0.84 \\
\hline
\end{tabular}

play, it is not this ranking of the direct effects that dominates the final effect for all the countries. In fact, Benin's industrial sector gains the most. When excluding the construction sector (which, again, benefits from the increased demand created by greater public expenditure), export agriculture (Senegal and Uganda), or mining and oil (Mali, Tanzania, and Cameroon) benefit the most.

The crop agriculture and private services sectors profit the least. We also observe a slight reduction in private services in Uganda, the only sector beside public services in any country not increasing output. Both agricultural prices (crop and export) fall in all countries except for Benin's export agriculture (rising 0.03 percent). Export agriculture decreases more than the crop agriculture in all countries but Benin. The construction prices increase from the demand pressure from the increase in investment but other prices do not follow a specific trend. Given the positive externality effects, most capital payment rates increase in all countries with the only exception this rate in mining and oil for Tanzania ( -0.08 percent) and Uganda $(-1.34$ percent $)$ and for the private services $(-0.08$ percent) in Uganda.

5.4. The Investment in Electricity Infrastructure. In this section, we analyze the investment on electricity infrastructure. 
The main characteristic versus the road infrastructure is that the main winners in terms of externalities are the industries, followed by the construction sector and mining and oil sector. Moreover, the operating costs of electricity infrastructure versus road infrastructure are 7 percent higher. It will require higher funding to sustain the operation cost compared to the road infrastructures.

5.4.1. Investment Funded by the Value Added Tax. The first funding option analyzed for electricity infrastructure investment is the value added tax (VAT). This funding option was also used for the nonproductive investment. We present the macro results in Table 15.

This is an interesting scenario to compare to the baseline case since the funding mechanism used here is the same in the two situations. However, before moving to this comparative analysis, let us compare with the previous one for the GDP growth. In this case, we have Senegal benefiting the most, followed by Cameroon. The ranking is quite different and this comes from the structural differences of the economies and the externalities of electricity investments. Like in the previous simulation analyzed, the country differences are relatively small going from 0.63 percent in Mali to a bigger growth of 0.83 percent in Senegal. In the case of road investment, the household gains were not systematically lower than the GDP growth. In fact, in three countries, it was the opposite. In this case, the growth of GDP dominates the household gains with the exception of Cameroon and Senegal where the gap is very small (less than 0.03 percent in the two countries). Another change is that the households gain more than firms in five of six countries. The only exception is in Tanzania where firm's income increases by 0.69 percent compared to 0.49 percent for households. We even have a negative impact on firm income for Benin. Because we have positive externalities all agents in all countries gain compared to the nonexternality option. Given the positive effect on firm's income in most countries and on household income, we have an increase in private savings and consequently in total private investment for all countries. The strongest increase is in Tanzania $(+1.72$ percent $)$ and weakest in Senegal by 0.41 percent. The eviction effect described in the nonproductive investment is completely eliminated by the externality effects. We did not get this clear effect in the two funding scenarios for the road investment as we get for the electricity investment.

The impact on the wage is similar in terms of intensity with the baseline and in terms of ranking of countries. In some case, the impact is larger here and in other cases, the change in wage rate was larger for the nonproductive investment case. We still observe relatively large differences in wage rate changes going from the largest change for Benin with +4.18 percent to +0.74 percent for Tanzania.

As for the exchange rate, we observe an increase in the nominal exchange rate, favoring an increase exports and a reduction of imports to clear the current account balance. The strongest effect on the nominal exchange rate is in Benin $(+1.43$ percent $)$ and the weakest in Mali ( +0.63 percent). We present the sectoral effect of the electricity investment with the VAT funding option in Table 16.
In light of these results, we can say that the elasticity of externalities does not play a dominant role in affecting sectors in the different countries; this is because these are the same as the baseline case. As in the previous simulation, we would expect the construction sector to do best because it profits from (1) the strong increase in demand and (2) its favorable ranking in terms of externality of electricity investment. We do observe this in all countries except in Uganda where the public services are the biggest winner for this option but in this case, it is the operation cost increase that accounts for the large public service increase. It is also quite surprising that the industry in Senegal and in Uganda see their output subside. This can be explained by the fact that in these two countries, the VAT is much higher in the goods produced by this sector compared with the other sector. It is also interesting (but not surprising) that the crop agriculture output falls or is constant in all countries, while export agriculture jumps slightly in Benin $(+0.24$ percent $)$ and in Cameroon $(+0.43$ percent $)$. Low electricity externalities are the reason.

With the exception of private services in Senegal and Tanzania, almost all market prices jump. These upswings have dampened the effects of higher wages on household welfare in each country studied. Comparisons of the ranking of market-price effects across countries do not reveal any particular trend.

When excluding the construction sector, we note, with the exception of Benin, a dwindling capital payment rate for industry. In Benin and Senegal, capital payment rates decline for private services. But all others rise or remain almost constant. The largest increases are seen in the two agricultural sectors and in mining and gas for all countriesagain, excluding the construction sector.

5.4.2. Electricity Investment Funded by Income Tax. In this section, we compare the second funding option for the electricity investments. It is the first time we look at funding investment with the household income tax increase. We would expect this option to be least favorable to households (as opposed to firms) at least in aggregate terms. This is because households fund these investments through higher taxes. At least, this is the partial equilibrium we would achieve. We have to keep in mind that we are working in a general equilibrium context and this can be different as the price and income effect are taken into account and in the VAT option, the consumers face higher prices, which also impairs their welfare. The macro results are presented in Table 17.

In this analysis, we compare the funding scenario with the VAT option presented above. Starting with the equivalent variation, we can compare the results with what we estimated would happen. In fact, the household impact is almost identical to the VAT option in all countries. We observe minuscule differences in four countries where the income tax option is more favorable-by 0.02 percent in Benin, Mali, and Tanzania and 0.07 percent more favorable in Cameroon. The impact on GDP is identical for all countries. The change in wage rates is stronger in all countries except for Senegal, where the effect is only slightly less than in the VAT case. The effect on firms' income is also quite similar, although 
TABLE 15: Macro results of electricity investments, funded by VAT (values in table are \% variations of variables with respect to reference period).

\begin{tabular}{|c|c|c|c|c|c|c|c|}
\hline \multirow{2}{*}{ Variable } & \multirow{2}{*}{ Definition } & \multicolumn{6}{|c|}{ Electricity (VAT funded) } \\
\hline & & Benin & Mali & Senegal & Tanzania & Uganda & Cameroon \\
\hline$Y m$ & Aggregate household income & 0.70 & 0.59 & 0.91 & 0.49 & 0.16 & 0.90 \\
\hline$E V$ & Equivalent variation & 0.62 & 0.57 & 0.84 & 0.47 & 0.16 & 0.83 \\
\hline$s$ & Wage & 4.18 & 0.83 & 2.02 & 0.74 & 0.27 & 1.40 \\
\hline$y g$ & Government income & 13.97 & 3.03 & 5.61 & 5.17 & 2.98 & 6.04 \\
\hline ye & Firms income & -0.04 & 0.56 & 0.41 & 0.69 & 0.06 & 0.10 \\
\hline$g$ & Total government expenditure & 10.77 & 1.56 & 4.84 & 3.17 & 2.24 & 6.54 \\
\hline It & Total private investment & 0.61 & 0.73 & 0.41 & 1.72 & 0.16 & 0.65 \\
\hline$e$ & Nominal exchange rate & 1.43 & 0.58 & 0.11 & 0.48 & 0.05 & 0.28 \\
\hline$G D P$ & GDP & 0.66 & 0.63 & 0.83 & 0.72 & 0.18 & 0.80 \\
\hline
\end{tabular}

TABLE 16: Sectoral results for electricity investments, VAT funded (values in table are \% variations of variables with respect to reference period).

\begin{tabular}{|c|c|c|c|c|c|c|c|}
\hline \multirow{2}{*}{ Variable } & \multirow{2}{*}{ Sector } & \multicolumn{6}{|c|}{ Electricity (VAT funded) } \\
\hline & & Benin & Mali & Senegal & Tanzania & Uganda & Cameroon \\
\hline \multirow{7}{*}{$V a$ (value added or output) } & Crop agriculture & -0.06 & 0.01 & 0.00 & -0.07 & -0.04 & -0.27 \\
\hline & Export agriculture & 0.24 & 0.27 & -0.15 & 0.15 & -0.06 & 0.43 \\
\hline & Mining and gas & & 0.41 & & 0.38 & 0.07 & 0.34 \\
\hline & Industries & 1.18 & 1.17 & -0.31 & 0.93 & -0.17 & 0.68 \\
\hline & Construction & & 1.65 & 3.56 & 2.26 & 1.29 & 7.03 \\
\hline & Private services & -0.05 & 0.88 & 0.91 & 0.94 & 0.14 & 0.49 \\
\hline & Public services & 6.96 & 1.03 & 3.51 & 1.85 & 1.88 & 3.61 \\
\hline \multirow{7}{*}{$p q$ Market prices } & Crop agriculture & 1.22 & 0.69 & 0.76 & 0.75 & 0.25 & 1.22 \\
\hline & Export agriculture & 2.60 & 0.45 & 0.54 & 0.54 & 0.15 & 1.41 \\
\hline & Mining and gas & & 0.93 & & 0.80 & 0.20 & 0.46 \\
\hline & Industries & 1.77 & 0.26 & 1.54 & 0.19 & 0.76 & 1.44 \\
\hline & Construction & & 0.34 & 4.89 & 0.63 & 0.73 & 1.37 \\
\hline & Private services & 2.37 & 0.01 & -0.72 & -0.15 & 0.35 & 0.78 \\
\hline & Public services & 3.56 & 0.50 & 1.29 & 0.53 & 0.35 & 1.34 \\
\hline \multirow{6}{*}{$r$ Borrowing rate of capital } & Crop agriculture & 1.12 & 0.74 & 1.20 & 0.62 & 0.19 & 1.03 \\
\hline & Export agriculture & 2.92 & 0.72 & 0.92 & 0.56 & -0.01 & 1.72 \\
\hline & Mining and gas & & 1.27 & & 0.99 & 0.15 & 0.45 \\
\hline & Industries & 0.21 & -0.86 & -0.76 & -0.99 & -1.13 & -1.47 \\
\hline & Construction & & 1.21 & 12.48 & 3.14 & 1.84 & 8.21 \\
\hline & Private services & -2.17 & 0.26 & -0.64 & 0.56 & 0.06 & 0.35 \\
\hline
\end{tabular}

TABLE 17: Macro results of electricity investments, funded by income tax (values in table are \% variations of variables with respect to reference period).

\begin{tabular}{|c|c|c|c|c|c|c|c|}
\hline \multirow{2}{*}{ Variables } & \multirow{2}{*}{ Definition } & \multicolumn{6}{|c|}{ Electricity (income tax funded) } \\
\hline & & Benin & Mali & Senegal & Tanzania & Uganda & Cameroon \\
\hline$Y m$ & Aggregate household income & 0.70 & 0.61 & 0.90 & 0.50 & 0.16 & 0.99 \\
\hline$E V$ & Equivalent variation & 0.64 & 0.59 & 0.84 & 0.49 & 0.16 & 0.90 \\
\hline$S$ & Wage & 4.52 & 0.99 & 2.00 & 0.77 & 0.28 & 1.59 \\
\hline$Y g$ & Government income & 13.97 & 3.03 & 5.61 & 5.17 & 2.98 & 6.04 \\
\hline Ye & Firms income & -0.10 & 0.50 & 0.41 & 0.65 & 0.06 & -0.11 \\
\hline$G$ & Total government expenditure & 10.77 & 1.56 & 4.84 & 3.17 & 2.24 & 6.54 \\
\hline It & Total private investment & 0.42 & 0.67 & 0.23 & 1.40 & -0.45 & 0.40 \\
\hline E & Nominal exchange rate & -1.13 & 0.06 & -1.09 & -0.34 & -1.96 & 0.80 \\
\hline GDP & GDP & 0.67 & 0.63 & 0.83 & 0.72 & 0.18 & 0.80 \\
\hline
\end{tabular}


the situation reverses for Cameroon, which falls from a +0.1 percent to -0.11 percent.

It is interesting that the strongest effects on the macro variable are on the nominal exchange rates. We had all rates rise and now they are plummeting in four countries. Uganda presents the starkest difference, falling from a 0.05 percent increase to a drop of 1.96 percent. Also, total investment in Uganda dwindled to 0.45 percent from what had been a positive effect of +0.16 percent. Overall, this funding option strongly resembles the VAT option-the greatest differences being the nominal exchange rates. The policymaker could therefore choose either option without creating major differentiated effects, at least at the macro level.

5.5. The Investment in Telecom Infrastructure. For our final investment option, we analyze telecom infrastructure investment. Here we have elected to look at the foreign aid and import duties funding options. As shown in the elasticity (see the appendix), the two services sector and the construction sector benefit the most. The two agricultural sectors also profit, followed by the industries and mining/gas sectors.

5.5.1. Investment Funded by Foreign Aid. We will focus our comparative analysis on the baseline and road investment as this option was also funded with foreign aid. The macro results are presented in Table 18.

This simulation provides an interesting result. The impact on GDP is almost identical for all countries. Taking into account the lower scale of the Uganda simulation, we would have results ranging from the low 0.42 percent increase in Cameroon to a high of 0.55 percent in Senegal. This is the most minimal country difference in all simulations analyzed until now. As for household impact, the effects are similar although they are more differentiated than that observed for the GDP. Cameroon presents the only exception to these similar results, as the positive effect on households is twice as large at the GDP increase. As in other simulations, the wage rate change is strongest in Benin (4.15 percent) and weakest in Tanzania ( 0.51 percent). For all countries except Tanzania, the household impact is more favorable than the impact on firms.

As for road investment funded by foreign aid, we observe an important currency appreciation (or a reduction in the nominal exchange rate) in all countries. In fact, the impact on the nominal exchange rate is almost the same in four countries and slightly lower for Mali ( -1.39 percent compared with-2.25 percent for road investment) and for Cameroon ( -5.51 percent compared with-6.31 percent for road investment).

Moving to the sectoral effects presented in the Table 19, we note that these effects are different among countries as opposed to the impact on the GDP (almost identical changes). In fact, the results are completely different from one country to the other. With the exception of Tanzania, the countries have two sectors that cut their production. Moreover, the ranked effects are completely different among the countries. We therefore cannot discuss specific trends at the sectoral output level for this scenario.
We observe that most prices drop in all countries. This phenomenon occurs in contrast to the options where taxes funded the investment. The ranking of price effects between countries is very different, where for Benin, the biggest decrease is in private services, Mali and Senegal in industries, Tanzania, Cameroon, and Uganda, in mining and gas. The crop agricultural and export agriculture prices decrease in Benin, Senegal, and Uganda, and in Cameroon and Tanzania, these two prices increase. But in Mali, the crop agriculture price rises while that for export agriculture falls. The price effects are felt most dramatically in Uganda, where vast amounts of foreign aid places strong pressure on the exchange rate and other prices.

Finally, the capital payment rates follow the same trend as other sectoral variables for this simulation; no specific trend is observed on the ranked effects. We note, however, that all rates rises for crop agriculture while export agriculture prices fell in five of six countries. Cameroon is the one exception observed, showing 0.44 percent growth. As in other simulations, the capital payment rate in Senegal ballooned for the construction sector, rising 15.8 percent; in Cameroon, it grew 9.9 percent. The capital payment rates in Tanzania are all below 1 percent; the steepest rise was in industries at 0.84 percent.

5.5.2. Investment Funded by Import Duties. Our final simulation analyzed is the investment in telecom infrastructure funded by import duties, which we can compare with the baseline scenario also funded by import duties. (see Table 20).

The impact of this type of funding on GDP is almost identical among countries and compared with the previous two simulations. As for the foreign aid-funded telecom infrastructure investment, households improve their situation in contrast to the reference period baseline scenariothe greatest effects are seen for Senegal and then for Cameroon. This differs from the previous case, where Cameroon was affected most profoundly. Moreover, when funded by foreign aid, the effect is still positive although stronger for households in all six countries. The country rankings are the same as in the previous simulation.

The impact on wages is weaker than it is with foreign aid-funded case, and the country rankings remain the same. The same situation is observed more for firms than for households - namely, the situation is improved in all countries vis-à-vis the foreign aid-funded option. Households win over firms in all countries but Tanzania. In that foreign aid-funded option, investment increased slightly in only two countries-Mali +0.26 percent and Tanzania 0.3 percent. But for this funding option, we observe a growth in investment in four countries while it plunges in Uganda and Cameroon. For the foreign aid-funded option, investment was not as negative for these two countries.

Finally, in this case, the nominal exchange rate is not under as much pressure as in the previous case; changes are all below 2 percent. The steepest drop is in Uganda $(-1.75$ percent $)$ and Cameroon $(-1.55)$ percent. We observe declines in the nominal exchange rate for all six countries. 
TABLE 18: Macro results of telecom investments, funded by foreign aid (values in table are \% variations of variables with respect to reference period).

\begin{tabular}{|c|c|c|c|c|c|c|c|}
\hline \multirow{2}{*}{ Variable } & \multirow{2}{*}{ Definition } & \multicolumn{6}{|c|}{ Telecom (funded by foreign aid ) } \\
\hline & & Benin & Mali & Senegal & Tanzania & Uganda & Cameroon \\
\hline$Y m$ & Aggregate household income & 0.49 & 0.50 & 0.65 & 0.32 & 0.14 & 0.82 \\
\hline$E V$ & Equivalent variation & 0.49 & 0.50 & 0.64 & 0.33 & 0.17 & 0.85 \\
\hline$s$ & Wage & 4.15 & 1.26 & 1.55 & 0.51 & 0.32 & 1.50 \\
\hline$y g$ & Government income & 12.79 & 2.77 & 5.13 & 4.73 & 2.73 & 5.53 \\
\hline ye & Firms income & -0.25 & 0.15 & 0.19 & 0.37 & -0.11 & -0.83 \\
\hline$g$ & Total government expenditure & 8.85 & 1.28 & 3.98 & 2.61 & 1.84 & 5.38 \\
\hline It & Total private investment & -0.05 & 0.26 & -0.45 & 0.30 & -3.46 & -0.76 \\
\hline$e$ & Nominal exchange rate & -4.96 & -1.39 & -4.27 & -1.87 & -11.38 & -5.51 \\
\hline$G D P$ & $G D P$ & 0.44 & 0.44 & 0.55 & 0.45 & 0.13 & 0.42 \\
\hline
\end{tabular}

TABLE 19: Sectoral results for telecom investments, funded by foreign aid (values in table are \% variations of variables with respect to reference period).

\begin{tabular}{|c|c|c|c|c|c|c|c|}
\hline \multirow{2}{*}{ Variable } & \multirow{2}{*}{ Sector } & \multicolumn{6}{|c|}{ Telecom (foreign aid) } \\
\hline & & Benin & Mali & Senegal & Tanzania & Uganda & Cameroon \\
\hline \multirow{7}{*}{$V a$ (value added or output) } & Crop agriculture & 0.26 & 0.28 & 0.37 & 0.20 & 0.08 & -0.43 \\
\hline & Export agriculture & 0.34 & 0.37 & -0.22 & 0.04 & -0.40 & -0.07 \\
\hline & Mining and gas & & -0.06 & & 0.29 & 0.92 & 0.04 \\
\hline & Industries & -1.64 & 0.39 & -0.53 & 0.44 & -1.33 & 0.18 \\
\hline & Construction & & 1.59 & 2.56 & 0.93 & 1.92 & 7.75 \\
\hline & Private services & -0.48 & 0.46 & 0.38 & 0.51 & 0.04 & 0.03 \\
\hline & Public services & 2.62 & 0.79 & 3.59 & 1.70 & 3.65 & 3.17 \\
\hline \multirow{7}{*}{$p q$ Market prices } & Crop agriculture & -0.30 & 0.19 & -0.78 & 0.07 & -0.15 & 0.68 \\
\hline & Export agriculture & -0.55 & -0.23 & -0.66 & 0.07 & -0.46 & 0.80 \\
\hline & Mining and gas & & -0.34 & & -1.06 & -9.60 & -5.42 \\
\hline & Industries & 0.51 & -0.83 & -1.79 & -0.51 & -4.39 & -0.68 \\
\hline & Construction & & -0.04 & 5.41 & -0.03 & -1.52 & -0.17 \\
\hline & Private services & -0.56 & -0.03 & -1.26 & -0.31 & -1.82 & 0.10 \\
\hline & Public services & 6.07 & 0.47 & 0.38 & 0.23 & -1.74 & 0.93 \\
\hline \multirow{6}{*}{$r$ Borrowing rate of capital } & Crop agriculture & 0.04 & 0.55 & 1.68 & 0.29 & 0.28 & 0.48 \\
\hline & Export agriculture & -0.38 & -0.18 & -0.19 & -0.14 & -0.76 & 0.44 \\
\hline & Mining and gas & & -2.09 & & 0.74 & 4.32 & -6.75 \\
\hline & Industries & 5.60 & 1.59 & -1.77 & 0.84 & -2.67 & 1.25 \\
\hline & Construction & & 2.37 & 15.80 & 0.80 & 3.23 & 9.90 \\
\hline & Private services & -3.02 & 0.50 & -0.98 & 0.13 & 0.10 & 0.25 \\
\hline
\end{tabular}

TABLe 20: Macro results of telecom investments, funded by import duties (Values in table are \% variations of variables with respect to reference period).

\begin{tabular}{|c|c|c|c|c|c|c|c|}
\hline \multirow{2}{*}{ Variable } & \multirow{2}{*}{ Definition } & \multicolumn{6}{|c|}{ Telecom (Import duties funded) } \\
\hline & & Benin & Mali & Senegal & Tanzania & Uganda & Cameroon \\
\hline$Y m$ & Aggregate household income & 0.48 & 0.46 & 0.62 & 0.31 & 0.12 & 0.60 \\
\hline$E V$ & Equivalent variation & 0.46 & 0.45 & 0.58 & 0.31 & 0.12 & 0.55 \\
\hline$S$ & Wage & 3.88 & 0.94 & 1.45 & 0.49 & 0.21 & 1.01 \\
\hline$Y g$ & Government income & 12.79 & 2.77 & 5.13 & 4.73 & 2.73 & 5.53 \\
\hline$Y e$ & Firms income & -0.21 & 0.26 & 0.22 & 0.40 & 0.03 & -0.27 \\
\hline$G$ & Total government expenditure & 8.85 & 1.28 & 3.98 & 2.61 & 1.84 & 5.38 \\
\hline It & Total private investment & 0.24 & 0.38 & 0.05 & 0.73 & -0.44 & -0.07 \\
\hline$E$ & Nominal exchange rate & -0.95 & -0.32 & -1.10 & -0.64 & -1.75 & -1.55 \\
\hline GDP & $G D P$ & 0.44 & 0.44 & 0.55 & 0.45 & 0.13 & 0.41 \\
\hline
\end{tabular}


TABLE 21: Externality parameter. Externality elasticities $(\xi)$ by sector.

\begin{tabular}{lcccccc}
\hline \multirow{2}{*}{ Investment } & \multicolumn{5}{c}{$\begin{array}{c}\text { SPameter } \\
\text { Sectors }\end{array}$} \\
& Crop agriculture & Export agriculture & Mining and gas & Industries & Construction & Private services \\
\hline Road & 0.05 & 0.075 & 0.085 & 0.035 & 0.055 & 0.025 \\
Electricity & 0.001 & 0.015 & 0.02 & 0.1 & 0.075 & 0.055 \\
telecom & 0.02 & 0.025 & 0.015 & 0.015 & 0.045 & 0.035 \\
\hline
\end{tabular}

\section{Conclusion}

The ambitious modeling exercise has allowed us to analyze the impact of scaling up infrastructure investment in six African countries with different economic structures as was described in the paper. The different economic structures have contributed to producing diversified results for the same type of investment funded by the same sources with the same model. The structure of the economy where these policies will be applied needs to be taken into account. Our analysis also shows that even with a relatively aggregated production structure in the models, we do not have such clear-cut sector that can be classified as tradable and nontradable sector. One often finds in the literature, production sector such as export agriculture classified in the tradable, but our figures reveal that most of the production in these sectors are destined to local industries that will eventually export part of its transformed product. We also have a construction sector in Tanzania that is tradable where it is nontradable in other countries. This is certainly at the source of the specific results in this country.

Another important conclusion is that if the current account needs to be balanced, funding investment through foreign aid produces the strongest sectoral effects. This is because strong price and nominal exchange rate adjustments are needed to clear the current account balance. The sectoral effects are strongly influenced by the structure of imports and exports observed in the different country as well as the size in the inflow of funds required to finance the public infrastructure. It is therefore important to analyze such reforms in a modeling context as disaggregated as possible and to fully take into account the structural characteristics of the country. The other important structural characteristic is the capital/labor ratio in the different productive sectors. This plays an important role in determining the winners and losers as relative effects on factor payments are strongly related to the capital/labor ratios.

An important caveat should be added to our findings. The characteristics of the different sectors in terms of export behavior and preferences between imports and locally produced goods in the different countries are likely to be quite different from one country to the other. We have assumed for comparative basis that these were the same. Relaxing this hypothesis would certainly have amplified the country differences we have observed in our analysis. A good illustration for this is preferences of national consumers for imported and locally produced rice. In certain countries, the consumers have a strong preference for Asian produced rice
(Senegal) and in others, they prefer locally produced rice (Mali). On the export side, a landlocked country will have smaller export CET elasticity than a coastal country with good port and airport infrastructure. These differences could be quite large. It is much more difficult for a landlocked country to export perishable agricultural products compared to a coastal country near large markets. One this is said, we can reiterate our objective to perform a comparative analysis by focusing on the structural differences and not behavioral differences. Hence, our results can be seen as lower bound case of differences with respect to the impact of scaling up public infrastructure in African economies. Adding these assumptions into the analysis would only have enriched our conclusions we have stated here and would reinforce the caveat of using aggregated models which distinguishing only two or three sectors such as tradable and nontradable sectors. On the other hand, the comparative analysis would have been more difficult with these differences in the models.

\section{Appendix}

See Table 21.

\section{References}

[1] R. J. Barro, "Economic growth in a cross section of countries," Quarterly Journal of Economics, vol. 106, no. 2, pp. 407-443, 1991.

[2] D. A. Aschauer, "Is public expenditure productive?" Journal of Monetary Economics, vol. 23, no. 2, pp. 177-200, 1989.

[3] A. H. Munnell, "Why has productivity declined? Productivity and public investment," The New England Economic Review, pp. 3-22, 1990.

[4] E. M. Bergman and D. Suan, "Infrastructure and manufacturing productivity: regional accessibility and development level effects," in Infrastructure and the Complexity of Economic development, D. F. Batten and C. Karlsson, Eds., pp. 17-35, Springer, Heidelberg, Germany, 1996.

[5] S. A. Binder and S. S. Smith, Politics or Principle?: Filibustering in the United States Senate, Brookings Institution, Washington, DC, USA, 1997.

[6] J. Hakfoort, "Public capital, private sector productivity and economic growt: a macroeconomic perspective," in Infrastructure and the Complexity of Economic Development. Advances in Spatial Science, D. F. Batten and C. Kalsson, Eds., pp. 61-72, Springer, Berlin, Germany, 1996.

[7] A. Estache, "Infrastructure and development: a survey of recent and upcoming issues," in Rethinking Infrastructure for Development-Annual World Bank Conference on Development 
Economics, Global, F. Bourguignon and B. Pleskovic, Eds., pp. 47-82, 2007.

[8] Asian Development Bank, Investing in Sustainable Infrastructure: Improving Lives in Asia and in the Pacific, Asian Development Bank, Manilla, Philippines, 2009.

[9] V. Foster and C. Briceño-Garmendia, "Africa’s infrastructure: a time for transformation," Agence Française de Développement and World Bank, Washington, DC, USA, 2010.

[10] S. Gupta, R. Powell, and Y. Yang, The Macroeconomic Challenges of Scaling Up Aid to Africa: A Checklist for Practitioners, International Monetary Fund, Washington, DC, USA, 2006.

[11] M. Foster and T. Killick, "What would doubling aid do for macroeconomic management in Africa?" Working Paper no. 264, Oversees Development Institute, London, UK, 2006.

[12] T. McKinley, "Why is the dutch disease always a disease? The macroeconomic consequences of scaling up overseas development assistance," Working Paper no. 10, International Poverty Centre, Brasília, Brazil , 2005.

[13] A. Berg, S. Aiyar, M. Hussain, S. Roache, T. Mirzoev, and A. Mahone, "The macroeconomics of scaling up aid: lessons from recent experience," IMF Occasional Papers, no. 253, 2007.

[14] Y. Li and F. Rowe, "Aid inflows and the real effective exchange rate in Tanzania," (Policy Research Working Paper Rep. No. 4456), Washington, DC, USA, The World Bank, 2007.

[15] J. Mongardini and B. Rayner, "Grants, remittances and the equilibrium real exchange rate in sub-saharan African countries," IMF Working Paper no 09/75, Washington: International Monetary Fund 2009.

[16] F. Bourguignon and M. Sundberg, "Absorptive Capacity and Achieving the MDG's," Working Papers RP 2006/47, World Institute for Development Economic Research (UNUWIDER), 2006.

[17] D. Hailu, "Scaling-up HIV and AIDS financing and the role of macroeconomic policies in Kenya," in IPC Conference Paper 4. Paper presented at the Global Conference on Gearing Macroeconomic Policies to Reverse the HIV/AIDS Epidemic, International Poverty Centre (IPC), Brasília, Brazil, November 2007.

[18] E. Abdullatif, "Crowding-out and crowding-in effects of government bonds market on private sector investment: a Japanese case study," Institute of Developing Economies, Discussion paper, no. 74, 2006.

[19] H. Ahmed and S. M. Miller, "Crowding-in and crowdingout effect of the components of government expenditure," Department of Economics, University of Connecticut, Working paper, no. 1999-02, 1999.

[20] L. Savard, "Scaling up infrastructure spending in the Philippines : a top-down bottom up micro-simulation approach," International Journal of Microsimulation, vol. 3, no. 1, pp. 4359, 2010.

[21] M. Bayoudh, Investissement en infrastructure publique et croissance en Tunisie: une analyse en équilibre général calculable [Ph.D. thesis], Université Laval, Québec, Canada, 2011.

[22] D. Boccanfuso, M. Joanis, P. Richard, and L. Savard, A Comparative Analysis of Funding Schemes for Public Infrastructure Spending in Quebec, Working paper no. 12-10, GREDI, Université de Sherbrooke, 2012.

[23] C. S. Adam and D. L. Bevan, "Aid and the supply side: public investment, export performance, and Dutch disease in lowincome countries," World Bank Economic Review, vol. 20, no. 2, pp. 261-290, 2006.

[24] S. Levy, "Public investment to reverse dutch disease: the case of chad," Journal of African Economies, vol. 16, no. 3, pp. 439-484, 2007.
[25] L. Savard and E. Adjovi, "Externalités de la santé et de l'éducation et bien-être: un MEGC appliqué au Bénin," Actualité Économique, vol. 74, no. 3, pp. 523-560, 1998.

[26] B. Decaluwé, A. Martens, and L. Savard, La Politique Economique du Développement et les Modèles D'équilibre Général Calculable, Association des Universités Francophones AUF-Presse de l'Université de Montréal, Montreal, Canada, 2001.

[27] P. S. Armington, "A theory of demand for products distinguished by place of production," International Monetary Fund, vol. 16, no. 1, pp. 159-178, 1969.

[28] M. Fay and T. Yepes, "Infrastructure: what is needed from 2,000 to 2010?” World Bank Policy Research Working Paper 3102, World Bank, Washington, DC, USA, 2003.

[29] J. C. Dumont and S. Mesplé-Somps, "Des retombées généralement bien appréciées: infrastructure publique, croissance et compétitivité au Sénégal," in La Politique Economique du Développement et les Modèles D'équilibre Général Calculable, B. Decaluwé, A. Martens, and L. Savard, Eds., Association des Universités Francophones AUF-Presse de l'Université de Montréal, Montreal, Canada, 2001.

[30] T. M. Harchaoui and F. Tarkhani, "Le capital public et sa contribution à la productivité sur secteur des entreprises du Canada," Statistique Canada, Document de recherche, no.11F0027MIF, 2003.

[31] S. R. Yeaple and S. S. Golub, "International productivity differences, infrastructure, and comparative advantage," Review of International Economics, vol. 15, no. 2, pp. 223-242, 2007.

[32] O. Bajo-Rubio and S. Sosvilla-Rivero, "Does public capital affect private sector performance?" Economic Modelling, vol. 10, no. 3, pp. 179-185, 1993.

[33] E. Gramlich, "Infrastructure investment: a review essay," Journal of Economic Literature, vol. 32, no. 3, pp. 1176-1196, 1994.

[34] S. Dessus and R. Herrera, "Le Rôle du Capital Public Dans la Croissance des Pays en Développement au Cours des Années 80," OECD Working Paper 115, Organisation for Economic Co-operation and Development, Paris, France, 1996.

[35] L. Savard, "Dépenses en infrastructures publiques et externalités positives de production: une modélisation en équilibre général appliqué au Québec," in Le Québec Economique, M. Joanis and L. Godbout, Eds., pp. 181-204, Presses de l'Université Laval, Québec, Canada, 2010. 


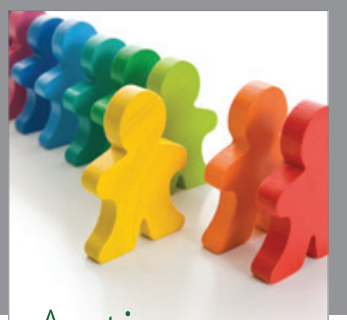

Autism

Research and Treatment
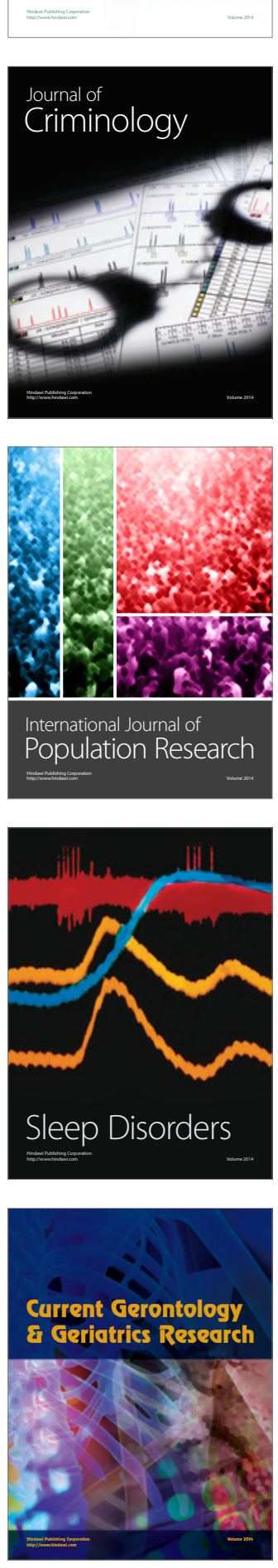
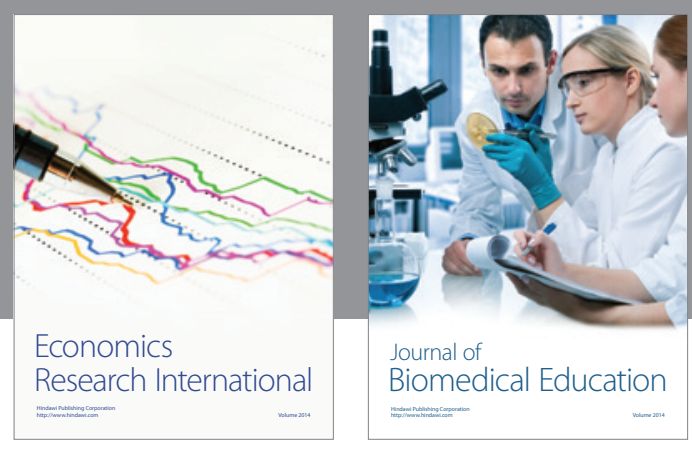

Journal of

Biomedical Education

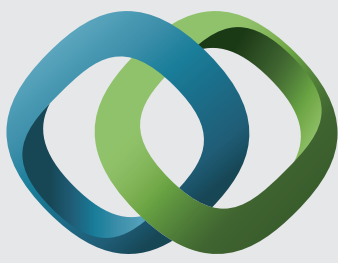

\section{Hindawi}

Submit your manuscripts at

http://www.hindawi.com
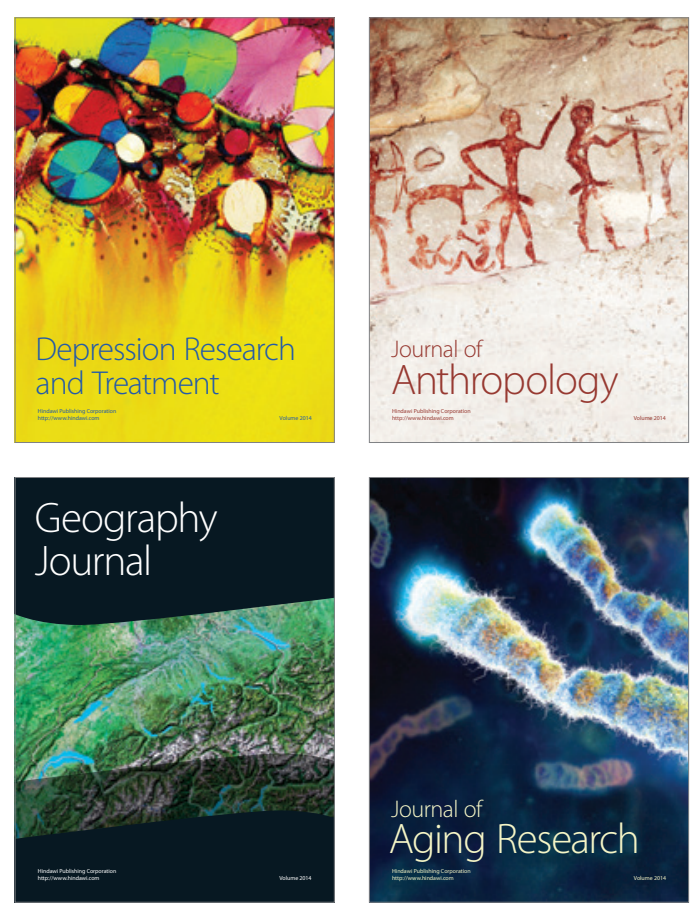

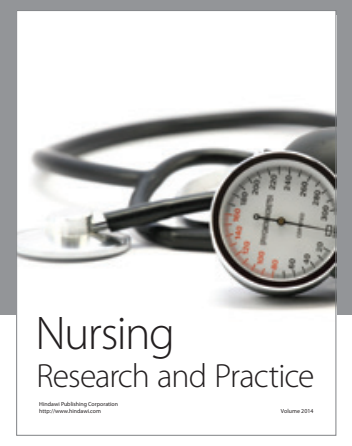

Nursing

Research and Practice

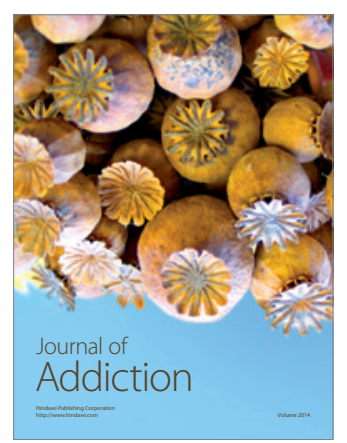

Child Development

Research

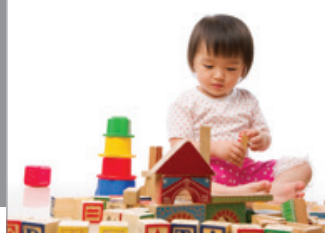

迥
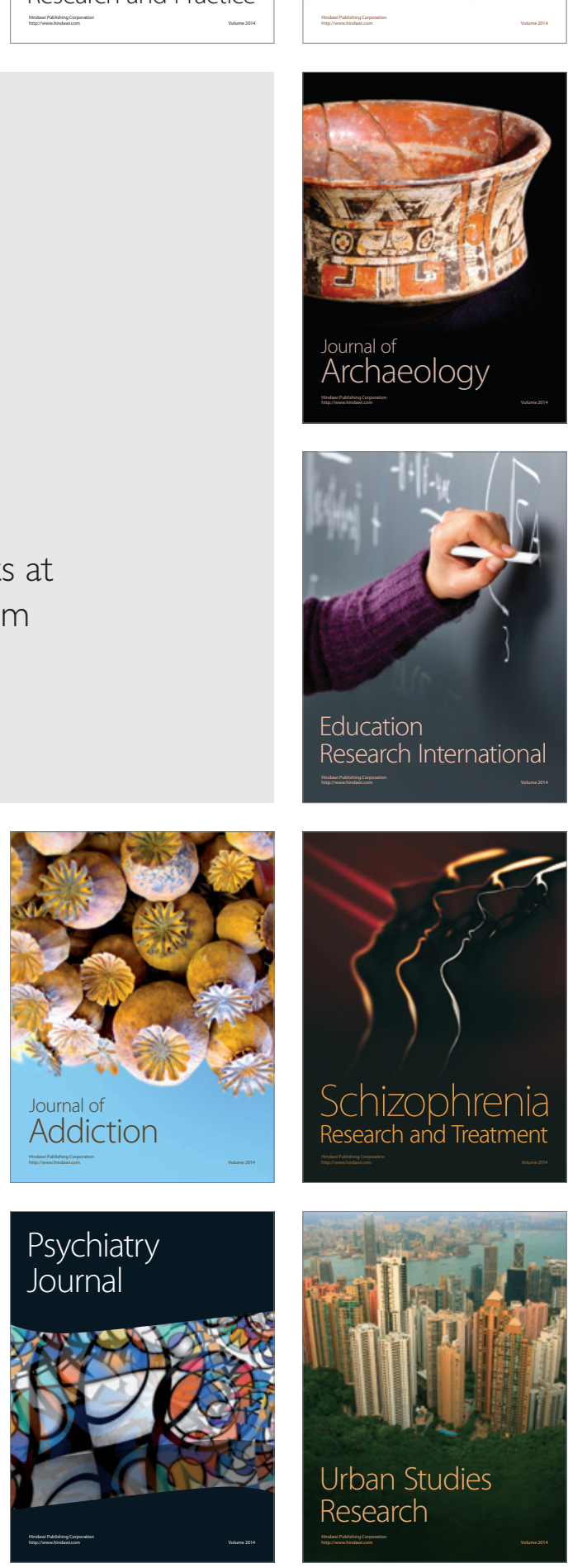